\title{
Historian Education In The Context Of Islamic Economic Development In Indonesia Part 1
}

\author{
Wahyudin Maguni, Herman, Rusdin Muhalling, Abdul Kadir \\ Lecturer State Islamic Institute (IAIN) Kendari, South East Sulawesi - Indonesia
}

\begin{abstract}
It is undeniable that the motion ripples education in Indonesia, especially in the educational development of sharia economy are becoming more evident and has become one of the options that can be felt and applied to almost all lines and aspects of community life in the sectors of education and economic development based syariah. Movement the importance of academic education in the economic development of sharia is not only a theory but a more distant and had effectively been implemented and a trend in motion coloring in a country's economy and one of them in Indonesia.Government since the last 24 years have been so serious and real in moving and jack up Islamic economic development that is not only aesthetically in the education sector but has also been evident in the institutional sector both financial and non-financial services companies and manufacturing. But not only there a need for human resources have the ability in sharia economy is needed and will remain always needed to be able to drive the economic development of sharia towards national development goals of the Republic of Indonesia, and this is inseparable from the role of educational institutions in which there are people who never give up and keep fighting in preparing the humans Indonesia tough in implementing and applying sharia economy in the life and activity of each day. And to be able to interpret it further and deeper it is necessary to lunge descriptive about the extent to which the economic development of sharia Indonesia occurred republic country.
\end{abstract}

Keywords: Education, Economic sharia

\section{PRELIMINARYBACKGROUND}

The economic development of Islam in the past three decades is progressing very rapidly, both in the form of an academic study in college or in operational practice. The attention of scientists to the economy ofIslam began inthe1960samongotherthingsdevelopedyDr.KursyidAhmadDr.M.N.ShiddiqyandDr.M.A.Mannan, Dr.M.Umer Chapra, etc. The fruits of their studies that were ushered establishment IDB (Islamic Development) in 1975 in Jeddah and the convening of the First International Conference on Islamic Economics in 1976 in Jeddah. The first conference is to serve as the initial momentum of the birth of modern Islamic economics.

Since the 1970 s the scientific study and research on Islamic economics empirical continue to be made and disseminated to various countries, so that the movement of Islamic economy growing academically. Since the 1990s, Islamic economic studies have been developed in various universities, both in Muslim countries (especially Asia and Africa) as well as in Western countries, such as in Europe, USA and Australia. In the UK there are several universities that have developed economic studies Islam (Islamic economics), such as the University of Durham, University of Portsmouth, Markfield Institute of Higher Education, University of Wales Lampeter, and Loughborough University. In the United States, a world's most prominent universities, namely Harvard University, are very active in the study of Islamic economics. Economists Islam there hosted Harvard Forum is annually held a seminar and workshop of Islamic economics. In Australia, the University of Wolongong also do the same. In Malaysia, an academic study of Islamic economics at the College has been started since 1983 .

In Indonesia, an academic study of Islamic economics in the College, a new bloom since the 2000s. IAIN North Sumatra is the earliest universities in developing Islamic economic studies in Indonesia, namely the establishment of the Economic Research Forum and the Islamic Bank (FKEBI) in 1990. FKEBI thus, born before the establishment of Bank Muamalat Indonesia in Jakarta in 1992.In line with the rise of an academic study of Islamic economics is no less prevalent is the development of shari'a banking and financial institutions other Shari'ah, then grow and develop also the massive Islamic economics education programs in Indonesia, as a response to the proliferation of financial institutions syari 'ah since 2005 until today the development of Shariah banking and insurance grew fantastically.On the other hand, Islamic Economics Academic Studies in Indonesia has been growing rapidly in the most prominent Universities in Indonesia, namely the University of Indonesia through the graduate program PSTTI. Since 2000 until now, has opened eight concentrations of Islamic economics at the University of Indonesia's S2 Program (Masters), there is a concentration of Shariah banking, insurance sharia, Accounting Shari'ah, the Shari'ah Management, Risk Management, Zakat and Waqf , Islamic 
Development Economics, and etc. Indonesia University since 2012 has opened the Doctoral Program in Islamic Economics.In addition to the University of Indonesia, which opened the College Studies Program and Department of Islamic economics is the Trisakti University, both S2 and S3 program by inviting lecturers from abroad. Due to the economic concerns of Shariah, then Thobi Muties (Rector of Trisakti) non-Muslims got syari'ah Award since 2004. Similarly Airlangga University through the role of Prof. Dr. Imam Suroso Djazuli, since the late 1990s, they have KONCERN developing Islamic economic studies through graduate program (S2).Meanwhile, Islamic University of Yogyakarta, since the beginning is also very concerned with the study of Islamic economics, either S1, S2 and S3. Gajah Mada University has also opened a concentration of Islamic Economics for Master Program (S2). Brawijaya University, IPB Bogor, and UMI Napier also known to be very caring and concerned about the study of Islamic Economics plus some Muhammadiyah University, both in Malang, Yogyakarta and Solo.The academic study of the phenomenon, is seen that the Public Higher Education, are more concerned and eager to develop economic studies Islam over Islamic Universities such as the Islamic University of Jakarta and other IAIN.Curriculum sharia economy today is increasingly in demand. The governments also incessant disseminate and implement curriculum-based economy sharia, in junior and senior high school or higher education level / University, Institute or College, this is a condition that is encouraging. The goal is that the understanding of sharia economics may instilled early. During the preparation of human resources syariah more focused on the college level. In fact, a similar request in middle and high school too much.Earlier, the National Education Ministry approved the Gajah Mada University (UGM) and the University of Indonesia (UI) opens Islamic economics programs. MONE give credence to IAEI to make recommendations for universities that want to open Islamic economics programs. Minister of National Education, hopes that more colleges open Islamic economic studies program at the level of S1 and diploma. Because Islamic finance industry is currently growing so it needs qualified human resources to meet those needs. With the start of the many colleges that open Islamic economics education program is expected to produce qualified human resources so that the Indonesian sharia banking industry can continue to thrive. One of the main problems currently facing the Islamic finance industry as a manifestation of Islamic economic practices in the world, including Indonesia, are the availability of qualified human resources. The continued development of Islamic banking and finance industry to encourage the growing need for qualified human resources. Bank Indonesia has declared to pursue Islamic banking market share to 5\% (five Ersen), Indonesian labor shortage of about 40 thousand. [1]

The second problem is the lack of public awareness of Islamic banking and finance system. It is seen from yet many people who access the services of Islamic banking compared to conventional banking services.

One of the world's largest management consulting firm, AT Kearney report limited qualified human resources in Islamic banking sector will be the biggest obstacle to developing it. Moreover, with the continued development of Islamic banking industry, the demand for newly qualified human resources will be even greater. AT Kearney predicts Middle East Islamic banking industry in the next decade will require at least about 30 thousand new human resources quality. According to Director of Dow Jones Islamic Market Index (DJIM), Rushi Siddiqui, limited resources also happen in terms of human resources sharia supervisory. Moreover, the need for HR is predicted to continue to increase as more conventional Western financial institutions began entering the Islamic business.Siddiqui said the latest data Islamic Finance Information Service (IFIS) in London shows the number of international Islamic scholars today are very limited. Since 2006, there were only 187 expert international Islamic sharia, which supervised the suitability for a total of 200 Islamic financial institutions in the world. Sheikh Nizam Yaquby Bahraini example supervises nearly 40 Islamic financial institutions. Siddiqui said that based on these data, proven world Islamic financial institutions still require the addition of more syariah experts. Currently, there are about 300 Islamic financial institutions in the world. They are spread over in 75 countries. Since 2008, the value of their assets is estimated to reach about 300 billion US dollars. The asset value was projected to grow significantly in the coming years triggered by the high market demand for Islamic financial products.(2) launch the results of research on the development of global Islamic finance. Based on that research, Islamic banking is a financial industry in the world with the most rapid growth rate. [2] However, when compared with conventional financial institutions is still very much the share market. For example, in Indonesia the Islamic banking market share is still below 3\% of national banks (2)However, the human resource needs of Islamic economics is really good quality is a basic requirement and urged to encourage the development of Islamic economics faster again. To that end, the existence of Islamic economics education institutions is a must.

\section{ERA OF GLOBAL ECONOMIC TREND}

The era of globalization (the age of globalization), in some of the literature revealed began in the 1990s. [3] This era was marked, including the presence of an important phenomenon in the economic field. World economic activity is not only limited by factors boundaries of geography, language, culture and ideology, but more because of the need each other and depends on each other. [4] The world becomes as if there is no limit, mainly due to the development of information technology so rapidly. Such situation gave birth to many 
opportunities and challenges, [5], especially in development efforts and development of Islamic economics. [6] The globalization process is estimated increasingly rapidly in the future, as stated by Colin Rose that the world is changing at the speed step is unprecedented. Community life including the legal and economic life is becoming increasingly complex. [7] Basically, the economic system refers to the unity of decision-making mechanisms and institutions that implement these decisions on production, consumption and income distribution. [8] Therefore, the economic system is something that is important for the economy of a country. The economic system is formed due to many complex factors, such ideologies and belief systems, way of life, environmental geography, political, social, cultural, and others.

In this global era there are various kinds of economic systems of countries in the world. Nevertheless, generally speaking, the economic system can be grouped in two poles, namely capitalism and socialism. Other systems such as the welfare state, state capitalism, market Socialisme; democratic sosialism basically works on the frame of capitalism and socialism. However, since the collapse of the Soviet Union, socialism is considered to have fallen along with the collapse of the Soviet Union. Therefore the capitalist economic system is still a strong economic system in the world.

The capitalist economic system which is currently growing, indeed not exactly the same as in the early days of birth. Evolution has occurred in the course of the capitalist system towards a more humane and ethical attention, as has been alluded to in the introduction to this article. The current economic era in the global era is often called the modern economic era or the new economy (the new economy). New Economy in fact of the whole industry (in the broad sense) competing in the order and new way. New Economy is not just about high technology, but rather to innovate in doing business, related to the products (goods / services) and so on. Productive activity in the New Economy of the issues and characteristics are almost similar, fast, global, networked, increasingly influenced / determined by knowledge, the more full of technology/ innovation.

New Economy economic differences with the old (previous) basically more on paradigm in implementing or managing and developing economic activity. New Economy heavily laden with the rapidly changing dynamics, activity that seems without limit (borderless), and the network is the pattern of everyday relationships that determine how the value added process is done, and how the relevance and competitiveness is built and maintained. More important is the fact that knowledge (knowledge) and innovation is considered as a main driver (the driving force) for the New Economy. This fact is for the moment more significant happens in other advanced economies.

In line with the New Economy is developing other jargon that the knowledge economy or knowledgebased economy. The knowledge economy (knowledge economy) is an economy that makes effective use of knowledge for economic and social development. This includes tapping foreign knowledge, adaptation and creates knowledge for specific needs (World Bank Institute). In another definition, Economy based on knowledge (knowledge-based economy / KBE) is basically economic in which the creation of (production), distribution (distribution) and utilization / utilization of knowledge was the main driver of growth, the development of well-being, and creation / expansion of the field employment in all industries / sectors of the economy as well as the opinion expressed by (McKeon and Weir, 2000).

Different terms that the New Economy, the knowledge economy, knowledge-based economy is actually speaking the same philosophical core. Essential essence of Modern Economic paradigm is that (1) Knowledge is one of the most important resources in development; (2) The ability of innovation increasingly determine the success of a business / economics; (3) Competence is the basis for the focus of productive activity; (4) Network / links of the value chain to be the pattern of economic activity best; (5) Factors locality increasingly decisive advantage in global competition (excellence in the governance of global competition is increasingly determined by the ability to compete with the best local potentials). [9]

Failures Capitalist Economy and the emerging school of Positive Economics Failure of conventional science capitalist in creating social justice and resolving human problems is not in dispute is already much in evidence and references pertaining failures including the story that can be directly seen in Countries that still apply and run the capitalist economic system. [10] Internationally it can be seen through the book The Death of Economics works Ormerod (1998) or through a book Nelson's Economics as Religion (2001). Nationally, it can be seen through the works of Economics Expose book Sri-Edi Swasono since (2005).

Something exciting is that there have been positive developments in economics, in which many economists have done a sharp critique of the failure of conventional economics capitalists and contributed his thoughts to express ideas that lead to recovery paradigm of economics for the better, ie attention to moral values, ethics, and social justice. For example put forward by Thomas Friedman as the Davos conference was held, in August 1997 which brings together leaders from around the world. He said which means: "The attack on those who will build the world on the basis of one-dimensional, where trading is everything, where only financial calculations are necessary, it will easily meet potential moral attacks against globalization". [11] 
Amitai Etzioni (1988) states that the paradigm of neoclassical economics is essentially not just ignore the moral dimension, but also rejected the inclusion of morality into the paradigm. Therefore, there needs to be a new paradigm in economics, namely the need to put moral values, because only in that way makes it possible to search for what is right and what is wrong. [12] Christofam Buarque (1993), states that the failure of economics in his view is the neglect of social values and ethics. [14] The social objective has been ruled out and is seen as a consequence of technical progress rather than as a goal of civilization. Meanwhile, ethical values have been marginalized. There needs to be a fundamental change in approach, a rearrangement of priorities in total. The approach is intended, namely: (13)

1. An ethic to do redifinisi about the purpose of civilization.

2. A new definition of objectives and areas of study

3. A new foundation for economics as a discipline. [15]

Timothy Gorringe stated that reducing human Homo sapiens (being wise) with only Homo economicus is rationally maximizing utility, acting originated self-interest alone is a reduction of a very crushing against moral values. [21] It is therefore necessary to establish tribunals international to economic justice. [16] Clive Hamilton revealed that economics hooked and agreed with human life, whereas humans are heartless besides understanding, therefore, ignore the feelings of the modern economy (moral / ethical) and spirituality is an important error margin. Understand something with just principle reason alone is an incomplete understanding. [17] Since the publication of Max Weber's The Protestant Ethic and the Spirit of Capitalism (1904-1905) convinced the close relationship between the (teachings) of religion and work ethic, or the application of religious teachings with economic development. Weber did begin with the analysis of the teachings of the Protestant (and Catholic), although towards the end of his life, also discussed Chinese religion (1915, Taoism and Confucianism), India (1916 Hindu and Buddhist), and Judaism (1917). [18] While Kurt W. Rothschild provides one method of settling the problem of ethics in economics. He stated that fairness (as one category of ethics) can be a bridge between fairness and efficiency in economics. Although there may be a little deviation from the idealized, but the basic conflict between the values of ethics and economics can only be conciliated through this way. [19] As with the Edward E. Zajac, in the book Political Economy of Fairness, he explains some of the theory of economic justice both normative and positive economics like John Rowls' Theory of Justice, Robert Nozick Theory of superfairness (normative) and Perceived Economic Justice in Public Utility Regulation (positive) and so on. The conversation in this book always link the macro and micro economy, as a source of moral problems in the economy, including the fact intimate no link between the macro and micro economics. It's as has been widely criticized on the division of macro and micro it is not finished. [20] Regarding the many criticisms of the conventional capitalistic economy, today has emerged various schools of positive economic critically, [21] including:

1. Grant Economics which states that altruistic behavior is not necessarily regarded as a bias against rasionaliti.

There needs to be integration between self-interest and altruism. Equalizing or simplify rational behavior only with selfish is not realistic.

2. Economic humanistic formation which emphasizes the principles of humanism to promote human welfare by recognizing and integrating basic human values. This sect does not adhere to the ancient utilitarian but humanistic psychology.

3. social economics which includes business to the economic theory of revolution combined with thought being given to moral considerations. According to Amartya Sen (2001), distanced economics of ethics means has shrunken welfare economics and also weakened the basis of descriptive and predictive economics. Hausaman, one of the supporters of this understanding, an economy that actively conduct self-criticism with moral aspects will become more attractive, brighter, and more helpful.

4. Institutional economics assumes that human behavior is influenced by various institutions interrelated social, economic, political, and religious. The difficulty encountered by conventional economics has been tested by a number of leading economists in a review, Economics in the Future: Towards a New Paradigm. [22].The consensus that emerges from this book is that it is necessary to save the economics of the crisis that is being experienced, not with an interpretation of this theory or that theory or make changes in the paradigm of economics, but what is needed is to change the paradigm itself and move towards a new paradigm in which economic problems are not to be considered separately, but studied in the context of the whole social system, in which the ideas, visions of society and moral values are not hidden, but getting a place in the parameters that affect the process of economic decision-making. [23] The modern economy has failed to ensure distributive justice, sustainable growth, human development that is balanced, and social harmony. The relationship between moral values, economic decisions and signs people have experienced a crisis during conventional capitalist economy.

According to Umar Chapra, [24] the scientific revolution in conventional economics is not complete, causing a lack of chain firmly between microeconomics and macroeconomics. Lack of the connecting link between macro-economic and micro-economy has caused discontent among the economists. It is in fact as if 
there is a contradiction between macro-economic and micro-economic. Micro-economic analysis based on the individual freedom of excessive pay more attention to the efficiency with Pareto, but do not pay attention to the realization of the objectives of macro-economic based on religious views.

In the context of the problem, the values of moral / ethical has the ability to assist in this task, because it can be used to create social cohesion by reducing the gap between the interests of individual and social in encouraging the use of resource-scarce resources in line with the need to realize the goal. [25] The market does not have the ability to carry out his duties. Markets need to be equipped with the moral values that help guide the individual preferences to in compliance with humanitarian purposes. The purpose of such is difficult to achieve in the absence of reform at the level of individual and social rhythm with moral values. [26] The problem is the source of moral values in the economy was taken, so that anyone who could break them punished. Is the social economy and several other positive schools can provide it? Whether of social morality? Maybe the answer is no. Because social morality depends on agreed as a consensus standard that is accepted as an axiom that can hardly be discussed. Utilitarianism and social contract cannot have the potential of providing values accepted by everyone.

Therefore, the discussion about the source of these values leads to a discussion of Islamic economics, both of which relate to paradigms, goals and methods. It is not meaningful to delete theories and sophisticated work in conventional economics, but enhance the scientific revolution carried out by conventional economics. Why Islamic economics? The short answer is because of the opportunity to create a consensus within the larger Muslim world if the discussion of the problem conducted within the framework of the Islamic world view. [27] Islamic Economics: New Trend of the Universal inevitably, that designation Islamic economy bears the impression diverse. For some people, the word "Islam" Islamic Economics positioned in a very exclusive, thus eliminating sanctity value as the order for all mankind (rahmatan lil'alamin). For others, the Islamic economy is described as economic concoction between capitalist and socialist stream, so that specific characteristics possessed by Islamic economics itself is missing.

Umar Chapra calls with Economic Tawhid Islamic economics. But in general it can be said as a divine economics. A reflection of the character of "Divinity" Islamic economics is not the aspect of economic actors certainly the culprit because humans - but the aspect of the rules or systems should be guided by economic actors. It is based on the belief that all economic factors including the human self is basically belongs to God, and to Him (the rules) are returned all affairs. [28] As the economy godless then Islamic Economics - to borrow a phrase from Ismail Al Faruqi - have a source of "normative values-imperative", as a reference binding. With access to the Divine rule, every human action has moral and religious values. Every human action should not be separated from the value, which is vertically reflecting good morals, and horizontally benefit both humans and other creatures. Islamic Economics' not popular at all. The popularity of Islamic economics can be said is still long. Therefore, often the question arises, whether Islam is a new economy at all? If you look at the history and the meaning contained in Islamic economics, it is not a new system. The argument for this: first, Islam as a divine religion the most recent is the religion which is guaranteed by God perfection, as confirmed Allah in Surah Al-Maidah (5): 3. On the other hand, Allah SWT has ensured the completeness of the contents of the Qur'an as a guide to mankind who believe in their role as a vicegerent of Allah on earth. This is confirmed his word Allah in Surah Al-An 'am (6): 38: this means: And no creature crawling on the earth and the birds that fly with both wings, but they (also) like you. Gone us negligent nothing in the Book [472], then to their Lord will be gathered.[472]

In a proportion of Al-Kitab mufassirin interpret it with Lawh Mahfudz as meaning that the fate of all beings it is written (set) in Lawh Mahfudz. And some who interpret the Quran with meaning: in the Quran that have no points of religion, norms, laws, wisdom-the wisdom and leadership to human happiness in this world and the hereafter, and happiness of beings in general, Second, history records that the Muslims had reached a golden age, which cannot be denied to anyone. During that time, so many contributions of Muslim scholars who remain highly recognized by all parties in the various fields of science to date, such as mathematics, astronomy, chemistry, physics, medicine, philosophy and so forth. History also proves, that it is difficult to accept common sense an advancement race with so many contributions in various fields of life and field of science without the support of early progress in the economic field. Third, history also records many prominent economists Muslims who live and prosper in his day each, like Tusi, Al-Farabi, Abu Yusuf, Ibn Taymiyyah, Al-Maqrizi, Shah Wali Allah, Ibn Khaldun and others. [29] Even the latter (Ibn Khaldun) is recognized by David Jean Boulakia [30] as follows: "Ibn Khaldun discovered a great number of fundamental economic Notions a few Centuries before official Reviews their births. He discovered the virtues and the necessity of a division of labor before (Adam) Smith and the principle of labor before Ricardo. He elaborated a theory of population before Malthus and INSISTED on the role of the state in the economy before Keynes. The economist who Rediscovered mechanisms that he had already found is too many to be named. "Those arguments and the above indicators can be used as supporting a very convincing that the Islamic economic system is not new at all. But it should be recognized that the system had triumphed have been immersed in a long time, and had been forgotten by some 
parties, because the strength of the two systems ever scramble sympathy of the world, namely the system of capitalism and socialism.

Islamic economic system has developed a new history in the modern era. According to Khurshid Ahmad, known as the father of Islamic Economics, there are four stages of development in the discourse of Islamic economic thought, namely:

1. First Phase, started when some scholars, who have no formal training in economics, but have an understanding of the problems of socio-economic at the time, tried to resolve the issue of interest. They argued that bank interest is forbidden and Muslims must abandon any connection with conventional banking. This period begins at approximately the mid-1930s and experienced a peak of progress in the late 1950s and early 1960s. At that time in Pakistan established a local Islamic bank which operates not on the flowers. Meanwhile in Egypt also established financial institutions operating in the interest not named Mit Ghomir Local Saving. These stages are still premature and try so that the impact is very limited. Nonetheless this stage has opened the door wide for further developments.

2. The second stage began in the late decades of the 1960s. At this stage the economists Muslims who are generally educated and trained at leading universities in the United States and Europe began to try to develop certain aspects of Islamic monetary system. They conduct economic analysis of the prohibition of riba (interest) and propose alternatives are not interest-based banking. A series of international conferences and seminars on Islamic economics and finance held a few times with invited experts, scholars, economists both Muslims and non-Muslims. The first international conference on Islamic economics was held in Makkah alMukarromah in 1976, followed by an international conference on Islam and the new International Economic Order in London in 1977. After that held various seminars on Monetary and Fiscal Economics and Islamic Banking in various countries. In the second stage it appears the names of famous Muslim economists throughout the Islamic world among other things Prof. Dr. Khurshid Ahmad, who was named as the father of Islamic economics, Dr. M. Umer Chapra, Dr. M. A. Mannan, Dr. Omar Zubair, Dr. Ahmad An-Najjar, Dr. Nejatullah M. Siddiqi, Dr. Fahim Khan, Dr. Munawar Iqbal, Dr. Muhammad Ariff, Dr. Anas Zarqa and others. They are Muslim economists were educated in the West, but to understand all that Islam as a way of life that is integral and comprehensive has its own economic system and if applied properly will be able to bring Muslims to the authoritative position in the eyes of the world.

3. The third stage is marked by concrete efforts to develop banking and financial institutions, non-usury both in the private sector and the government sector. This stage is concrete synergies between the intellectual and material efforts of economists, experts, bankers, businessmen and the wealthy Muslims who have a concern for the development of Islamic economics. At this stage already started to set up Islamic banks and investment firms based non-usury with a clear concept and understanding of the more established economies. Islamic banks that were first established is the Islamic Development Bank (IDB) in 1975 in Jeddah, Saudi Arabia.

4. The fourth stage is characterized by the development of a more integrative approach and sophisticated to build the whole theory and practice of Islamic economy, especially the financial institutions and banking into the economic indicators of the people.

5. The main purpose of Islamic economics is to realize human goals to achieve happiness of the world and the hereafter (Falah), as well as a good life and a respectable (al-hayah al-tayyibah). [31] This is the definition of prosperity in the view of Islam, which is of course a fundamentally different with the understanding of economic prosperity in the conventional secular and materialistic. [32] Therefore the purpose of Islamic economic system is hooked up with the goal that not only meets the welfare of the world's only (materialist), but also the welfare of the more essential (hereafter). Allah SWT as the top destination, with the advanced search keridloan Him in everything from the behavior patterns of consumption, production to distribution. [33] Islamic economics represent a systematic effort has been made by Muslim economists to look at the overall economic problems, including the methodology of the economy with a view to delivering a new solution to issues of long and now is still disturbing. [34] This approach is still in initial growth stages, but no doubt that he is a promising start very big future and scintillating. [35]

Umer Chapra, is one among Muslim thinkers who did a very comprehensive study on the future of economic science in the Islamic view. His book, entitled The Future of Economics: an Islamic Perspective, has given a very positive contribution in this area. He has made a great effort to reconnect economics with morality and justice, thus enforcing discipline to defend human values. In the book, he conducted scientific criticism and sympathetic to conventional economics, from an economic as well as moral. He noted the limitations and advantages. He did not only criticize but also provide solutions. His approach is very creative and positive. He saw where one has moved in the wrong direction and ask what it takes to straighten it. The concern is not just limited to the moral and social dimensions, but also strengthens the micro foundations of economics necessary to enable them to strengthen the foundation of the macro framework and achieve social objectives. He put the Islamic economics in a position that is not separated by conventional economics. He examines the economic problems with glasses Islam comprehensively to get a new view of economic science fair, concerned with 
ethical and spiritual values. This study has been explained in brief but dense and high level of Islamic economics. The explanation is not a survey within the meaning of the technique; it presents a great view of the main contributions to economics made of perspective Islam by Islamic economists in the past century This book has contributed to new approaches to understanding the past and plan for the future. The main message of this book is that the economics require moral enrichment of Islamic perspectives so it really useful to humanity in the search for a more equitable world orders. Thus, the presence of Islamic economics is a response to efforts to close the flaws and weaknesses of conventional economics, so that Islamic economics is a continuation refinement of conventional economic development.

Prospects of Islamic Economic Education the development of Islamic economic practices, particularly in the areas of finance and banking, both globally and in Indonesia is very encouraging. At the world level, there are many countries that sharia banking and finance industry. Currently no less than 75 countries around the world have been practicing Islamic economic and financial system, both in Asia, Europe, America and Australia.

Similarly, in the academic field, several leading universities in the world are actively developing the academic study of sharia economy. Harvard University is a university that is actively developing forums and studies the sharia economy. [36] In the UK at least six universities develop economic studies Shari'ah. Similarly, in Australia by Mettwally and some European countries as do Volker Nienhaus. Scientists of Islamic economics, not only among Muslims but also non-Muslims. Economic development of the practice of Islam in Indonesia also pointed to the fact that encouraging. Since the last fifteen years, the development of Islam in Indonesia Economic discourse to appeal to many people, both from the aspect of conceptual / academic and practical aspects. From the academic side, the development of Islamic economy marked by numerous educational institutions that offer training programs or courses of Islamic Economics, Islamic Finance and Islamic Banking at both the Bachelor (S1) and Postgraduate level (S2 and S3).

At the level of formal education are Program Islamic Economic Studies of the Faculty of Islamic Studies, Islamic University of Indonesia, [37] SBI institute, SEBI, STEI Yogyakarta, Department of Islamic Economics STAIN Surakarta, UIN Syarif Hidayatullah in Ciputat, UIN Yogyakarta, IAIN Medan, and the Faculty of Economics UNAIR, STEI Tazkia, and the Department of Middle East and Islamic UI and other efforts of some Islamic universities and high schools of Islam that is quite a lot.

Development of education [38] has a strategic role as a factor for the realization of the reliability of Human Resources (HR) [39] which is required as one of the authorized capital of the sustainability of national development. [40] Therefore, the development of education is the responsibility of all parties, both private and public. [41] Moreover, the times in the future that is characterized by technological progress is very rapid and high levels of turbulence changes in the economic environment, social, cultural, and political, requires the readiness of human resources 'plenary' on the side academic levels. [42] SDM is a way that is characterized by the ability of analysis and prediction of reliable, motivated by the provision of a comprehensive theoretical and accompanied with high integrity to develop disciplines practiced. Armed with the determination expected role of universities in improving the quality of human resources through improving the quality of national education will be increased. [42] In addition, the developments of Islamic economics talks are also conducted through trainings, seminars, symposiums, [43] conferences, study books and other activities more depth on the development of Islamic economics and its application in the world of economics and business. Among the training institute that is; Tazkia Institute, Shariah Economic and Banking Institute (SEBI), the Centre for Training and Development Resources Mandiri (PPSDM), Muamalat Institute, Karim Bussiness Consulting and Sharia Banking Division of the Indonesian Bankers Institute (IBI).

In its application, the development of the system of Islamic Economics marked by numerous financial institutions Shariah established as Islamic Banking, Baitul Mal Wat-Tamwil, Islamic Capital Market, Mutual Funds Sharia, the Islamic pawnshop, Takaful and other institutions run by the principles Sharia. More and more financial institutions are principle basic principles of Sharia provide greater alternatives for the public to use the financial institutions that are not based on the interest system (conventional financial institutions). Observing the development of Islamic economy both globally and locally is rapidly increasing that, in the context of the trend of economic globalization, we need a strategy that is more focused and clear that Islamic economics increasingly get a solid place in the economic development of the future, so the immediate realization of economic era immoral, equitable, and godless. Based on the situation, the economic development strategy of Islam most unnecessary attention to two fundamental aspects, namely the conceptual aspects / academia and implementable / practical of Islamic Economics. Development of conceptual aspects more emphasis on the development of Islamic Economics as a science or system, while the development of implementable emphasis on the development aspects of Islamic Economics as applied to business institutions that implement Sharia principles in running their business. Both aspects should be developed jointly so as to form the Islamic Economic System that can be used to explore the potential and ability of people (the world and Indonesia) to 
build an alternative economic system as a substitute or a complement to conventional economic system that already exists.

Islamic Economic Development be pursued by involving various parties, both individually and institutionally. Thinkers continue to try to explore and discuss the economic system of Islam seriously and to inform the public through seminars, symposia, writing or via the Internet and other media. On the part of the practitioner or the relevant people doing business also continued to improve and implement the Islamic Economic system in accordance with the principles of Sharia allowed to carry out their business. Thus the development of Islamic economy is expected to be in line between conceptual and business practices in accordance with the existing guidelines that will eventually form the Islamic Economic system that is truly in accordance with Syariah principles outlined.

On the government side, the development of Islamic economy can be accelerated by making laws that are used as the formal grounding in conducting business activities based on a system of Islamic Economics, Law No. 19 Year 2008 concerning Government Sharia Securities, Law No. 21 of 2008 concerning Islamic Banking. In the realm of public finances, there is Law No. 38 of 1999 on zakat, Law No. 41 of 2004 on endowments, and others. [44] One example of momentum and at the same advantages facts Islamic banks than conventional banks in Indonesia by the end of 2006. The end of 2006 gave a fantastic record of the superiority of the Islamic banking system, which is one important aspect of Islamic Sharia in the economy compared to conventional banking. This is evident from the comparison of some aspects of the operating performance of the banking system include the Non-Performing Loans / Financing (NPL / NPF), Financing / Loan to Deposit Ratio (FDR / LDR), bank deposits at SBI or SWBIs, and its performance in the real sector. This fact should form the basis for the government to make regulations that make more Islamic banks can thrive. Moreover, this fact also should be "open" the eyes and hearts of all the Indonesian Muslim community in particular and the Indonesian people as a whole to more earnestly implement Islamic Sharia in the economy as a whole, because the empirical evidence of its superiority, especially in the aspect of banking is not refuted again. [45] At the global plains, more and more western financial institutions that offer a wide range of Islamic financial products. As did Citigroup, Deutsche Bank, HSBC, Lloyds TSB and UBS. However, the rapid development of the Islamic financial is not followed in the number of human resources (HR) of sufficient quality. Netherlands and Russia also developed Islamic banking.

Observing this phenomenon, the development strategy of Islamic economy is not quite done through education at the College of Islamic Economics. Even the basic material needs of Islamic economics began to be taught at the high school level, either the first level or above. Economic subjects at the high school must enter sub discussion of Islamic economics in the learning process. The inclusion of Islamic Economics lessons at high school rankings, the concept and characteristics of Islamic economics can be introduced early so that the public will get to know and understand the application of the system of Islamic Economics. Thus, at the college level, the teaching of Islamic economics does not start from a very fundamental level, can directly lead to a more advanced, so as to realize the Islamic economy of qualified human resources will be more affordable.

Among other challenges faced in the development of Islamic economics education, whom are not many funding agencies that provide research funds and scholarships for students of Islamic economics. [46] Therefore, there needs to be an effort that is more focused and systematic, and creatively to dig sourcealternative sources of funds in order to meet the need to fund the development of Islamic economics education. One alternative, for example by empowering institutions waqf, zakat, alms as media infaq and collecting charitable fund for the benefit of maslahah Ummah Muslims.

Abbas Mirakhor proposed that the economic approach in the assessment of Islam (in education institutions) also uses hermeneutical approach. This approach is different from the interpretation, because the nature of hermeneutical is the process of extracting economic meaning from the first-order interpretation. [47] This approach is expected Islamic economic future will be rich with economic theories are actually based on the Qur'an and Sunnah,

Among other challenges facing the economy development Islam in Indonesia is the lack of public awareness of Islamic banking and finance system. It is seen from yet many people who access the services of Islamic banking compared to conventional banking services. For that we need a strategy that a much more telling to the public. Even if you have put in place in the campaign of Islamic economics in society. This is for example the way to build a consensus reached by all takmir mosques in Indonesia to simultaneously themes Friday sermon in a given month are specifically talking about Islamic economics. So there is a kind of national movement that pivots in the mosque as a center for community education on the theme in Islamic economics.

\section{CONCLUSION}

Of the various explanations above we can conclude that conventional onomics does not only have weaknesses but also strengths. Its weakness lies primarily to the secular paradigm that separates between positive and normative economics, the absence of strong links between the micro and macro economics, neglect of moral values and ethics indescriptiveandpredictivefunctions. Thesurplusistosophistificated its achievement 
conventional economic theories with mathematical models and calculus. The era of globalization and the development trend of economics phenomenon has spawned a lot of opportunities and challenges, particularly in the development of Islamic economics. Therefore, the future development of Islamic economics, in addition to need to learn from the success and failure of conventional economics, should also take advantage of new approaches to creative and innovative can really realize the Islamic economy rahmatan lil'alamin in its various aspects. Among them is through education of Islamic economics, both formal and non-formal education. Of course that relied on to give birth to qualified human resources in the field of Islamic economics is a formal education, not only in universities, but also educational levels underneath. Observing the development of Islamic economics education as exposure to the above, it is worth us optimistic that education Islamic economy will be more prepared and adequate to deliver the quality of human resources in the field of Islamic economics. It can be concluded that the economic prospects of Islamic education in the context of global economic trends getting brighter and promising.

\section{BIBLIOGRAPHY}

[1] HU Republika, May 2, 2007www.researchandmarkets.com, Friday, June 13, 2008Globalization is accepted as one of the fundamentals of the processes that characterize the contemporary world, a process leading towards an increasingly strong interdependence between increasingly large parts of the world. S. Parvez Manzoor. 2004. "Book Review of 'Islam in the Era of Globalization:

[2] Muslim Attitudes towards Modernity and Identity" by Johan Meuleman (ed.). 2002. London: RoutledgeCurzon, published in the Journal of Islamic Studies, Vol. 15, No. 2, May 2004, Oxford: Oxford Centre for Islamic Studies, p. 280.

[3] Jan Pronk. 2001. "Globalization: A Developmental Approach", in January Nederveen Pieterse (ed.), Global Futures, Shaping Globalization, London: Zed Books, p. 43.

[4] Walter Leimgruber. 2004. Between Global and Local, Aldershot (England): Ashgate Publishing Limited, pp. $18-19$.

[5] For a more complete description of the experience and the response of Muslims to globalization, see Abdul Rashid Moten. 2005. "Modenization and The Process of Globalization: The Muslim Experience and Responses", in K.S. Nathan and Mohammad Hashim Kamali (eds.), Islam in Southeast Asia: Political, Social and Strategiec Challenges for the 21st Century, Singapore: Institute of Southeast Asian Studies, pp. 231-255.

[6] Colin Rose and Malcolm J. Nicholl. 1997. Accelerated Learning for the 21 st Century. New York: Delacorte Press, p. 1.

[7] Paul R Gregory and Robert C. Stuart. 1981. Comparative Economic Systems, Boston: Houghton Miffin Company, p. 16.

[8] [9]http://www.corebest.net/teori,_model,_metoda_dan_teknik_implementasi.htm, access to 24 September 2007

[9] As quoted Khursid Ahmad of the New York Times, 28 November 1993

[10] As quoted by Khursid Ahmad in the "Preface" Umer Chapra book, The Future of Economics: An Islamic Perspective. Khursid Ahmad (2001), "Introduction" in Umer Chapra. 2001. Future Economy: A Review of Islam. Ikhwan Abidin Basri (trans.) Jakarta: Gema Insani Press, p. xvii.

[11] Amitay Etzioni. 1988. The Moral Dimensioan: Towards a New Economics (New York: McMillan, pp. Ix-X.

[12] Christofam Buarque. 1993. The End of Economics: Ethics and Disorder of Progress. London, Zed Books, p. xi.

[13] According to Didi Hafidhuddin, the destruction of the current economic system because the paradigm of capitalist and socialist thinking that has made the human desires as controlling economic activity, rather than morals, ethics and morals. See Didier Hafidhuddin. 2002. Zakat in Modern Economy. Jakarta: Gema Insani Press, p. 67.

[14] Christofam Buarque. 1993. op.cit., P. xii[16] Timothy Gorringe. 1999. Fair Shares: Ethics and the Global Economy. Slovenia: Thames \& Hudson, p. 31.Ibid., P. 101

[15] Clive Hamilton. 1994. The Mystic Economist. Australia: Hamilton, h. 6-7. See also Masudul Alam C. 1989. The Paradigm of Humanomics. Bangi: SMEs

[16] Mubyarto. 2002. "Implementation of Economic Teachings of Islam in Indonesia" in the Journal of Economic Pancasila, Th. I - No. 1 - March 2002, http://www.ekonomirakyat.org/edisi 1 / articles 4.htm

[17] Kurt W. Rothschild. 1993. Ethics and Economic Theory. Cambridge: Edward Elgar, h. 152

[18] Edward E. Zajac. 1995. The Political Economy of Fairness. London: MIT Press

[19] M.B. Hendrie Anto. 2003. Introduction to Micro Economics Islami. Yogyakarta: EKONISIA, h. 16 
[20] As quoted Khursid Ahmad in the "Preface" Umer Chapra book, The Future of Economics: An Islamic Perspective. op.cit. h. xix

[21] See also Peter Koslowski exposure. 1993. "The Business of Business is Ethical Business" in Peter Koslowski and Shionoya. 1993. The Good and the Economical, Ethical Choice in Economics and Management. London: Springer-Verlag, p. 4

[22] Umer Chapra. 2001. Future Economy: A Review of Islam / the Future of Economics: An Islamic Perspective. Ikhwan Abidin Basri (trans.) Jakarta: Gema Insani Press, p. 33

[23] To get more notice about the use of scarce resources to keep pace with the need to realize the purpose of the expenditure in Islam, see Rustam Effendi. 2003. Production in Islam. Yogyakarta: Magistra Insania Press.

[24] Umer Chapra. 2001. op.cit., P. 34Ibid., P. 44Surah Ali Imran: 109.M. Abdul Mannan. 1986. Islamic Economics, Theory and Practice. Cambride: Hodder and Stoughton, the Islamic Academy; M. Umar Chapra. 2001. What is Islamic Economics, Jeddah: IRTI - IDB, h. 44.

[25] David Jean C. Boulakia. 1971. "Ibn Khaldun: A Fourteenth Century Economist", Journal of Political Economy, Vol. 79, No. 5 (September / October), the University of Chicago, h. 1117-1118.

[26] Al-Quran mentions the word falah in 40 places. Falah includes the concept of happiness in two dimensions: the world and the hereafter. Happiness earthly dimension, falah includes three aspects, namely: (1) survival, (2) freedom from poverty, (3) the strength and honor. While the dimensions of happiness hereafter, Falah also includes three aspects, namely: (1) the survival of the eternal afterlife, (2) the eternal welfare, (3) knowledge that is free from all such foolishness. Falah can only be achieved with a good life tatatan and respected (hayah al-tayyibah). See M. B. Hendrie Anto. 2003. op.cit., P. 7.

[27] Muhammad Akram Khan. 1989. "Methodology of Islamic Economics" in Aidit Ghazali and Syed Omar (eds.), Readings in the Concept and Methodology of Islamic Economics, Petaling Jaya: Lemur Publications, p. 59; Syed Mohd. Wafa Wafa Syed Ghazali Adwam et al. 2005. op.cit. h. 53; M. B. Hendrie Anto. 2003. op.cit., P. 7.

[28] Anas Zarqa'. 1989."Islamic Economics: An Approach to Human Welfare", in Aidit Ghazali and Syed Omar (eds.), Readings in the Concept and Methodology of Islamic Economics, Petaling Jaya: Lemur Publications, p. 29-38.

[29] Rizal Yahya. 2003. "An Analysis on the Anglo-Saxon Corporate Governance Model Based on Islamic Perspective" in ISEFID Review: Journal of The Slamic Economic Forum for Indonesian Development, Vol. 2, No. 1, 2003, p. 25Khursid Ahmad. 2001. op.cit., P. xx-xxi

[30] The name of the forum is The Harvard University Forum on Islamic Finance. The Forum is held every two years. The first Forum in May 1997, the topic "Islamic Finance in the Global Market," followed 100 participants. Forum 2nd, "Islamic Finance into the 21st Century," held two days followed by more than 200 participants, the 3rd Forum, "Islamic Finance: Local Challenges, Global Opportunities,". 4th Forum, "Islamic Finance: The Task Ahead". Forum 5th, "Islamic Finance: Dynamics and Development" covered theoretical and practical, current and upcoming issues at that time in Islamic finance and economics, in addition to the Shari'a. Forum 6th, "Islamic Finance: Current Legal and Regulatory Issues" was held 8-9 May 2004 by uniting Several topics of current interest in the field of Islamic finance. Forum-7, "Integrating Islamic Finance in the Mainstream Regulation, Standardization and Transparency", held April 2006.

[31] To find out how the patterns of educational development in the various regions of the world, can read books I.N. Thut (1984), entitled Educational Patterns in Contempporary Societies, translated by SPA Teamwork entitled Patterns of Education in Contemporary masyarakat, Student Library published in 2005.

[32] M. Enoch Markum (2007), Higher Education and Development in Historical Perspective in Indonesia. Jakarta: Indonesian University Publishers, p. 4-5.

[33] Djohar (2006), National Education Development toward the Future. Yogyakarta: Graphic Beautiful, p. 5, 9 and 98-104.

[34] Yusuf Emir Faisal (1995), Reorientation of Islamic Education. Jakarta: Gema Insani Press, p. 49-50

[35] H.A.R Tilaar (2002), Rebuilding National Education. Jakarta: PT Rineka Copyright, p. 2-10. See also Anita Lie (2004), "Education in the Dynamics of Globalization" in Indonesian Human Education. Jakarta: PT Kompas, p. 217-225.

[36] Haidar Putra Daulay (2004), Islamic Education in National Education System in Indonesia. Jakarta: Prenada Media, p. 133-135. See also Abuddin Nata (2003), Education Management Overcoming the weakness of Islamic education in Indonesia. Jakarta: Prenada Media, p. 77-83.

[37] National Symposium on Islamic Economics (SIMPONAS) in Indonesia organized two annual all. 2009 is SIMPONAS 4th, held in Yogyakarta. The host is UII together several universities in DIY. If you are interested in getting proceedingnya (free), please contact email: nurkholis@ fiai.uii.ac.id. 
[38] For more information on the law and various other laws related, could browse in www.bpkp.go.id/unit/hukum/.pdf

[39] A Riawan Amin. 2006. "Policy Reorientation Banking", article in the national HU Republika, December 4, 2006.

[40] Abbas Mirakhor. 2007. A Note on Islamic Economics, Jeddah: Islamic Research and Training Institute, p. 23. 